\title{
Current collective engagement stakeholder strategies for South African labour relations
}

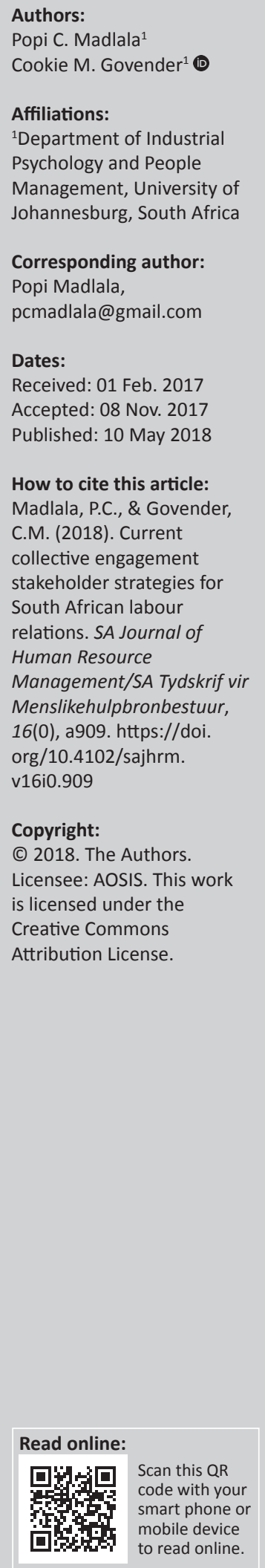

Orientation: Collective engagement stakeholder strategies are significant for the creation of harmony in the workplace. It is a known fact that the South African (SA) labour environment has been dominated by industrial action before and after the 1994 democratic transition. To be precise, the statistics reveals that industrial action has increased and become more destructive post-1994.

Purpose: The purpose of this article was to present the current collective engagement stakeholder strategies for South African labour relations.

Motivation for the study: The SA mining sector has seen more violent strikes, with a higher number of deaths, injuries, criminal activities, arrests, dismissals and job losses in recent years. This article captures the current mining stakeholder strategies shaping the existing labour relations environment.

Research approach, design and method: This is a theoretical article highlighting the recent literature on collective engagement in the mining sector in South Africa.

Main findings: This article presents the current labour relations incidents, reflecting the need for more effective collective engagement and stakeholder management strategies.

Practical and managerial implications: The current labour relations context has prompted key stakeholders at the National Economic Development and Labour Council (NEDLAC) to look specifically at promoting employment, labour market stability, the right to strike, minimising violence through collective bargaining and highlighting the role of the state, reducing vulnerability through social protection and increasing the minimum wage.

Contribution or value add: This article adds theoretically to the existing body of knowledge regarding collective engagement and stakeholder strategies in the SA mining sector.

\section{Introduction and background to the problem}

The status of South African (SA) collective engagement has failed to transform to the desirable level since the democratisation of the labour relations environment, with the promulgation of the Labour Relations Act (No. 66 of 1995) (OECD, 2000). Chinguno (2013) argued that democracy and violence should have an inverse relationship. However, in South Africa, violence remains a significant phenomenon despite the transition to democracy, both in the labour relations environment and in society as a whole. This demonstrates the lack of a collaborative collective engagement strategy.

According to Nwankwo (2016), collective engagement refers to the negotiation, administration and interpretation of a written agreement between two parties that covers a specific period of time. The International Labour Organization (ILO) has defined collective engagement as negotiations on working conditions and terms of employment between an employer, or a group of employers, and one or more employee organisations, with a view to reaching an agreement. The terms of that agreement serve as a contract, defining the rights and obligations of each party (Nwankwo, 2016). Most importantly, the collective agreement must shape the labour relations landscape in a more positive way.

Although the current collective engagement framework is deemed to be comprehensive and sufficient, the evidence collected by various analysts (as would be presented in the discussions that follow) suggests that there is a need to overhaul the current stakeholder collective engagement strategies (Coleman, 2013; Congress of South African Trade Unions [COSATU], 2012; Hartford, 2012). The current collective engagement in the mining environment, especially 
in the decentralised environment, leaves much to be desired and suggests that there is room for further strategic improvements at all levels of the bargaining process.

This theoretical article presents the current collective engagement strategies for labour relations by current stakeholders and adds value by contributing to the theoretical knowledge regarding collective engagement strategies in the mining sector in SA. It also adds value in a practical way by contributing to the debate on what strategies union and employer managers and leaders should utilise to create harmonious labour relations in the mining sector.

\section{Current collective engagement stakeholder strategies}

The current collective engagement strategies are presented under the subheadings of collective engagement framework in SA, an overview of the current SA collective engagement strategy and external factors impacting SA collective engagement strategies.

\section{Collective engagement framework in South Africa}

According to Sachs (2013), the labour law regime provides for unionisation that requires workers to organise for the purpose of collective engagement. Sachs suggests that the process of collective engagement has also been captured by political influences, where public policies and financial regulations are designed to facilitate political organising by the poor and middle classes, through collective engagement. Collective engagement practices and strategies in the SA mining sector were in the spotlight even before the shocking killings of mineworkers in Marikana in 2012. The statutory collective engagement framework is provided by the Labour Relations Act (LRA), as presented in Table 1, and describes the functions and powers of key stakeholders as governed by statutory legislation in SA (Coleman, 2013).

The workplace collective engagement framework, as provided for by legislated guidance on collective agreements, is outlined in Table 2. The table describes the stakeholder platforms, the functions and the powers of each.

It is expected that with such a well-designed framework, the SA mines should be able to contain unnecessary tensions that lead to unwanted conflict. The government has accepted that the industrial action experiences at the Marikana Platinum Mine in 2012 prompted the SA Government to reinforce social discourse and collective engagement. According to the Department of Labour (DoL), it was noted that the relapse of industrial disputes is a symptom of the failure of social discourse in the working environment, and persistent inequality is because of the ineffectiveness of policy implementation strategy in the SA labour market (DoL, 2012). The other reality is the absence of effective collective engagement strategies from the key collective engagement
TABLE 1: Levels of statutory bargaining in South Africa.

\begin{tabular}{|c|c|c|}
\hline Governed by statute & Functions and powers & Registration \\
\hline Bargaining councils & $\begin{array}{l}\text { - Make and enforce } \\
\text { collective agreements. } \\
\text { - Prevent and resolve labour } \\
\text { disputes. } \\
\text { - Establish and manage a } \\
\text { dispute resolution fund. } \\
\text { - Promote and establish } \\
\text { training and education } \\
\text { schemes. } \\
\text { - Establish and manage } \\
\text { schemes or funds to } \\
\text { benefit its parties or } \\
\text { members. } \\
\text { Make and submit } \\
\text { proposals on policies and } \\
\text { laws that affect a sector } \\
\text { or area. }\end{array}$ & $\begin{array}{l}\text { - May be formed by one or } \\
\text { more registered trade } \\
\text { union/s and one or more } \\
\text { registered employers' } \\
\text { organisation/s, given that } \\
\text { these parties are } \\
\text { 'sufficiently } \\
\text { representative'. } \\
\text { - NEDLAC is assigned the } \\
\text { task of determining their } \\
\text { scope and area of } \\
\text { justification. }\end{array}$ \\
\hline Statutory councils & $\begin{array}{l}\text { - Resolve labour disputes. } \\
\text { - Promote and manage } \\
\text { education and training } \\
\text { schemes. } \\
\text { - Form and manage schemes } \\
\text { or funds for the benefit of } \\
\text { its parties and members. } \\
\text { - Make collective agreements. } \\
\text { - May perform any other } \\
\text { bargaining council functions. }\end{array}$ & $\begin{array}{l}\text { - May be formed by a } \\
\text { registered trade union or } \\
\text { employers' organisation } \\
\text { that does not boast } \\
\text { sufficient membership to } \\
\text { meet the representation } \\
\text { requirement to form a } \\
\text { bargaining council. } \\
\text { Registration is thus } \\
\text { unilateral. }\end{array}$ \\
\hline
\end{tabular}

Source: Adapted from the Organization for Economic Co-operation and Development (OECD). (2000). Tackling inequalities in Brazil, China, India and South Africa. The role of labour market and social policies. Paris: OECD; and Coleman, N. (2013). Towards new collective bargaining, wage and social protection strategies in South Africa - Learning from the Brazilian experience. Global Labour University, Working Paper No. 17. Retrieved November 17, 2013, from http://www.global-labour-university.org

NEDLAC, National Economic Development and Labour Council.

TABLE 2: Current levels of workplace collective engagement in South Africa.

\begin{tabular}{|c|c|c|}
\hline Outside of statute & Functions and powers & Description \\
\hline $\begin{array}{l}\text { Plant or firm-level } \\
\text { bargaining }\end{array}$ & $\begin{array}{l}\text { Bargain over issues } \\
\text { otherwise covered by } \\
\text { Bargaining or Statutory } \\
\text { Councils. }\end{array}$ & $\begin{array}{l}\text { Collective bargaining } \\
\text { between an individual } \\
\text { employer and the trade } \\
\text { union(s) representing the } \\
\text { employees of that particular } \\
\text { employer. }\end{array}$ \\
\hline Workplace forums & $\begin{array}{l}\text { - Promote the workers' } \\
\text { interests by consulting and } \\
\text { making joint decisions. } \\
\text { Employers must provide } \\
\text { relevant information to } \\
\text { workplace forums. } \\
\text { - A workplace forum has the } \\
\text { right to be consulted by the } \\
\text { employer on: } \\
\text { - restructuring existing and } \\
\text { - pew work methods } \\
\text { - partial or total plant } \\
\text { closure } \\
\text { - mergers and ownership } \\
\text { transfers } \\
\text { - retrenching workers } \\
\text { - job grading } \\
\text { - criteria for merits and } \\
\text { bonuses } \\
\text { - education and training } \\
\text { - product development } \\
\text { plans } \\
\text { - export promotions } \\
\text { - health and safety } \\
\text { measures. }\end{array}$ & $\begin{array}{l}\text { - Workplace forums may be } \\
\text { formed when there are more } \\
\text { than } 100 \text { people by applying } \\
\text { to the Commission for } \\
\text { Conciliation, Mediation and } \\
\text { Arbitration (CCMA). }\end{array}$ \\
\hline
\end{tabular}

Source: Adapted from the Organization for Economic Co-operation and Development (OECD). (2000). Tackling inequalities in Brazil, China, India and South Africa. The role of labour market and social policies. Paris: OECD; and Coleman, N. (2013). Towards new collective bargaining, wage and social protection strategies in South Africa - Learning from the Brazilian experience. Gage and social protection strategies in South Africa-Learning from the Brazilian experience. Global Labour University, Working
www.global-labour-university.org

stakeholder representatives to eradicate the existing collective engagement challenges.

The Minister of Labour indicated that the one thing that needed to be dealt with regarding the Marikana incident was the re-establishment of the bargaining system in the platinum mines (DoL, 2012). The minister suggested a multi-pronged approach in the collective engagement system and suggested ensuring that all relevant stakeholders be included in the 
dialogue (DoL, 2012). This paper seeks to locate the reasons for the failures in the collective engagement system, and thereafter to make recommendations that will contribute to the current debate on the subject.

Hartford (2012) argued that the most noticeable feature of the events preceding the mining strike upsurge is the lack of any form of analysis of the economic- and social-democratic drivers. Hartford suggested that the lack of analysis led to the collapse of established collective bargaining institutions, agreements and norms in the labour relations process. Hartford's viewpoint recommended a review of the collective engagement framework to explore strategies that will ensure the harmonisation of the labour relations climate in the SA mining environment.

The Farlam Commission of Inquiry report of 2015 underlined the fact that the processes of collective bargaining are embedded in the SA Constitution and in a set of sophisticated enactments, central to which is the LRA (Farlam, Hemraj \& Tokota 2015). The labour relations dispensation is, at its core, a framework for officially organised union and employer entities, functioning within a bargaining environment that not only normalises their interface but also provides for the possibility of resorting to lawful strike or lockout measures (Farlam et al., 2015).

The intention of the LRA in establishing the bargaining councils is to centralise the collective engagement process to be sector specific (South African Government, 2015). Centralised collective engagement assists in creating consistent patterns of employment conditions within the same sector. The gold and coal sectors have a centralised collective engagement system, and history reveals that the mines in these sectors have competitive employment conditions. As much as the legislation's intentions to regulate collective engagement are good, the negative connotation is that it acts as a deterrent for inclusive collective engagement. The legislation excludes smaller trade unions in crucial stages of collective engagement and where it matters most. For example, in collective bargaining, only significantly recognised trade unions are given a passport to collective engagement. Kruger and Tshoose (2013) cited legislation as one of the hindrances, as it shuts the minority out of the collective engagement process, especially when dealing with crucial employee socio-economic issues. They argued that Section 23 of the LRA specifically excludes the minority, as it allows for the collective agreement with a significantly representative trade union to be imposed on all minority trade unions (Kruger \& Tshoose, 2013). This exclusion amounts to exclusion based on freedom of association, as the interests represented by smaller trade unions may be ignored.

The weaknesses and shortcomings in the labour legislation are that it does not provide for employee participation in decision-making in the mining sector (Kruger \& Tshoose, 2013; Lester, 2014). The argument is that workplace forums can contribute significantly to creating worker participation in the collective engagement process; however, the current labour legislation dispensation leaves the establishment of the workplace forum to the trade unions rather than the employer. Labour analysts suggested a review of the legislation in order to ensure broader participation in the collective engagement process (Lester, 2014).

Harvey (2013) argued that the current institutional labour relations policy framework perpetuates trade union rivalry to value violence over cooperation, amongst other causes. The argument is that the clear existence of a policy dilemma in the labour relations landscape within SA's mining industry warrants strategic redesign to avert the damaging effects of mutual inconstancy. A possible means of attaining the focal goal would be to mandate the legislator to remove bargaining rights from any union guilty of endorsing illegal or violent strike action (Harvey, 2013). According to Coleman (2013), the following recommendations are to be noted: the overhaul of the collective engagement system, an integrated proposal connecting the transformation of collective bargaining to a wage and income strategy and the transformation of social protection. According to the suggestion, the recommendation is for wages, social protection and collective bargaining to be brought together into one coherent package.

From the above discussion, it is clear that the current collective engagement framework in SA, especially in the mining industry, needs to be overhauled. This can be achieved through peaceful negotiation, engagement, winwin intentions and a powerful collective engagement strategy. The objective of this article is to review the current stakeholder collective engagement strategies and deduce the intention of leaders, managers and unions in bringing about a peaceful labour relations environment in the mining sector of SA.

\section{Overview of the current South African collective engagement strategy}

The Farlam Commission of Inquiry report identified inconsistent engagement strategies that contributed significantly to the instability in the collective engagement processes (Farlam et al., 2015). For instance, the National Union of Mineworkers (NUM) was involved in a collective engagement process with Implats on the Rock Drill Operators (RDOs) conditions of employment, which lifted the Implats RDOs above the industry norm. National Union of Mineworkers should have been aware of what the consequences of its achievement at Implats would be on its constituencies in surrounding mines. Furthermore, the union failed to negotiate similar conditions successfully for its members at the Lonmin mine. In recent times, after the Marikana debacle, similar to RDO, demands have been made and realised in other mines in SA (Farlam et al., 2015).

Collective engagement strategies of trade unions and employers shape the pay equity effects of a minimum wage 
policy (Grimshaw, Bosch \& Rubery, 2014). This was further supported by the outcome of the study conducted by Karen Roberts in 2015, which recorded the results as showing a difference between collaboratively and competitively bargained contracts in two areas, namely, direct responses to a changing national minimum wage and responses to the absence or weakness of a national minimum wage (Roberts, 2015). The Marikana debacle raises the debate about the best-fit strategy between decentralised and centralised collective bargaining, wherein the question that arises is: Of decentralisation and centralisation, which is the better strategy? Currently, the platinum mining sector practices decentralised collective bargaining, unlike the gold and coal sectors. Some have argued that the platinum sector was sufficiently similar to that of the gold mining sector to warrant centralised bargaining, notwithstanding the general problems associated with the practice (Chinguno, 2015; Lester, 2014).

Dawkins (2014) concluded that substantive operational indicators of collective engagement are lacking in the literature to guide collective engagement stakeholders on effective strategies for managing collective engagement. Earlier, Coleman (2013) postulated that the labour movements, and labour in general, are faced with the need to introduce new quality strategies to advance the wages and social protection of workers in the labour market. COSATU (2012) suggested that a more offensive strategic perspective to substantially restructure the current collective engagement architecture is required to confront the failures of the current SA national collective engagement system, which has failed to meet its objectives. New public policies and regulatory frameworks ought to be proposed to promote the consolidation of centralised engagement, a developmental engagement framework which increases wage equity, and the alignment of centralised bargaining with industrial and economic development strategies (COSATU, 2012).

A paper on new collective bargaining, learnt from experiences in Brazil, was presented by COSATU in 2012, which suggested that to achieve the new way of collective bargaining, some shortcomings from the existing system needed to be identified. The identified gaps, included, among others the need to develop new strategies to advance the position of workers in the labour market qualitatively. The COSATU paper identified that the key stakeholders have not succeeded in fundamentally changing the apartheid wage structure, with the partial exception of the public service and local government, and some pockets of the manufacturing sector, such as metal and engineering, and less so in the mining sector. There is a lack of centralisation of collective engagement in the platinum mining sector that has created severe inequalities amongst mining operations in this sector. The current gains achieved through the collective engagement process are deemed to be less efficient in real terms or sometimes reflect no change in real wages and lifestyle. There is therefore the danger that current strategies are in critical respects reinforcing the cheap labour structure of apartheid. The paper highlighted that there is widespread poverty amongst workers which remains a serious problem in SA. This is attributed to the high levels of unemployment and lack of social protection, leading to a greater dependency on low wages.

Having realised these challenges and the need to review the national collective engagement strategy in SA, COSATU proposed the following strategic intent: the need to campaign for the adoption of a national minimum wage; the need for the development of federation-style collective bargaining strategies, especially to reconfigure the pay structure; the need for the introduction of legislated mandatory centralised bargaining; the need to campaign for universal income support to cover all adults; the package of labour market and social protection measures should form the basis of a national agreement through the National Growth Plan (NGP), which is connected to an overhaul of the SA macro-economic policies; and, where employment is threatened in crisis-hit industries, a package of rescue measures needs to be devised and implemented by the parties, together with the government (COSATU, 2012).

An analysis of the Marikana Commission of Enquiry report identified eight emerging conditions lacking in the strategies of collective engagement stakeholders (South African Board of People Practices [SABPP], 2015). The first omission is that it is not easy to build a relationship of trust through collective engagement with employees as long as employees' living conditions are unpleasant and outside the mine premises. The second omission is that collective engagement failed to adequately match investment in employee housing to the cycles of platinum prices. The third omission is that there was a failure of the parties to engage thoroughly, separately and collectively on matters. The fourth omission is that most of the time, compromises and consensus are only considered during the dispute phase of the collective engagement process and when emotions are out of control. The fifth omission is that the failure to continue engaging during a dispute fuels the destructive nature of a strike. The sixth omission is the use or intervention of non-collective engagement agents during a dispute or strike situation, which causes havoc and raises emotions. The seventh omission is the lack of a communication strategy or contingency plan to deal with a strike situation that threatens to be disastrous. Lastly, there is a failure to listen to minority parties during a strike situation that can extend the size of the strike, as those unions or employees not involved in a dispute may be prevented from continuing with regular work. This results in forcing non-striking employees to continue working as normal during a volatile strike, putting the lives of innocent people at risk. Management needs to assess the risks and institute action that will protect non-striking employees (SABPP, 2015).

The SABPP picked up lessons from the Marikana debacle and suggested the following strategies as the way forward for collective engagement in the workplace. The first suggestion is the creation of a climate of trust, cooperation and stability within an organisation. The second suggestion 
is achieving a harmonious and productive working environment which enables the organisation to compete effectively in its marketplace. The third suggestion is to establish a framework for conflict resolution. The fourth suggestion is to establish a framework for collective bargaining, where relevant. The fifth suggestion is ensuring capacity building and compliance to relevant labour legislation and codes of good practice as per the ILO and DoL standards. The sixth suggestion is that management must at all times give honest information about its financial circumstances and ensure that employees understand the information. The seventh suggestion is that commitments made to any plan or agreement must be adhered to, or stakeholders must be involved in any proposed changes to those commitments. The eighth suggestion is that information on any change in the employment relations climate, which may occur from many different causes, should be gathered and carefully evaluated. Lastly, all stakeholders should be involved sooner rather than later in the resolution of disputes (SABPP, 2015)

As a major labour movement in the country, COSATU has accepted that the status of collective engagement requires a major strategic overhaul (Coleman, 2013). COSATU has acknowledged that the labour markets are facing significant challenges, which include the following: collective bargaining institutions becoming fragmented and constantly being destabilised, no coherent wage policy in the country to address poverty and inequality amongst workers and no consistent framework to link labour market strategies and institutions to a broader economic development strategy (Coleman, 2013).

There are a number of interventions that can restore the SA mining industry to a good, healthy state, specifically if jointly driven by stakeholders (government, labour movements and employers) who have the will to modernise and transform the industry. Hartford (2012) endorsed the following essential interventions: transforming and investing in the migrant labour system to modernise labour migrancy through a new migratory labour model founded on human dignity and the promotion of the mining industry as an employment attractor; short work cycles and continuous operations; significant pay rewards in a flatter remuneration structure on re organised work processes; modern, adequate living quarters for migrants underpinned by an efficient migrant commuter transport network (flight, rail or road); restoring migrant nuclear families to good health and banking facilities to facilitating maximum remittances to rural areas; overhauling stakeholder relationships and transforming or enabling the front-line managers to understand freedom of association, worker democracy, positively managing people, problem resolution capacity, union rights, levels of bargaining and recognition procedures; ensuring constituency-based union accountability and democracy; deepening freedom of association and democratic processes for union accountability in bargaining units, rights of shop stewards and threshold representation levels; rapidly transforming line management function to create language synergy and strong interpersonal problem-solving skills; restoring line function to be accountable for people problem resolution and employee communication, and measuring and rewarding line management for effective people problem resolution and effective communication.

Elgoibar, Munduate and Euwema (2016) highlight trust as a deterrent and argue that a good trust relationship is critical in the management of inevitable tensions and conflicts of interest related to change, and in the process of repairing broken relationships between management and employees, and their representatives. At Marikana, the employees did not trust either NUM or management, and for this reason wanted to engage on their own with the company representatives; thus, they felt excluded by both parties. As an alternative, the RDOs turned to the Association of Mineworkers and Construction Union (AMCU) for assistance with their bargaining issues, and soon most other job category employees also diverted to AMCU.

Webster (2013) cited that the engaging parties' ability to compromise is a possible limitation to harmonious collective engagement. Furthermore, the inability of the social partners to implement a delicate concession seems to be hampered by the complex legacy of SA's apartheid past. With the above discussion in mind, one wonders whether a collective engagement framework, as outlined in Tables 1 and 2, is considered by stakeholders in the mining sector when attempting to create sustainable harmonious policies, strategies, procedures and practices. It is evident from the literature review that there is an empirical research gap in stakeholder strategies for managing collective engagement in SA mines.

Whether the proposed collective engagement strategy changes will overhaul the mining industry remains to be tested in practice. It seems that the current intentions and strategies of the current collective engagement stakeholders in SA may not be geared towards co-creating harmonious working environments in the country because of internal and external factors.

\section{External factors impacting South African collective engagement strategies}

External circumstances can impact internal employment relations processes. Hence, the collective engagement stakeholder representatives must continually scan and evaluate the external environment. The lack of attention paid to the conditions under which employees live, and attempting to improve socio-economic conditions of employees, means that leaders and managers are less likely to pay attention to radical elements from inside or outside. The external factors impacting the SA collective engagement strategies are presented under the subheadings of legacy and sociopolitical factors and global labour market influences. 


\section{Legacy issues and socio-political factors}

Benjamin (2005) argued that attempts were made in the early post-apartheid period to forge a more social, democratic and coordinated variety of capitalism; however, this floundered as the government adopted neoliberal macro-economic policies against the wishes of organised labour. Hence, black economic empowerment policies further undermined an already racially fraught business sector. Di Paola and PonsVignon (2013) concur with Coleman (2013) to confirm the reports produced by the International Monetary Fund (IMF), which state that the SA Government has yielded to feared warnings of populism in the labour market. They argued that market flexibility has been destroyed by rigid rules established for overprotected workers who are poorly skilled or over-unionised. This is a deadly mix that results in high unemployment and poverty.

The shift in the political environment of the country, meanwhile, has had a more fundamental transformative impact, shaking the institutional underpinnings of collective bargaining in the mining sector (Szabó, 2013). The SA mining industry is challenged by the need to address a number of legacy issues that promote a undesirable review of the industry and perpetuate discontent, leading to potential policy change (Humby, 2016). Humby suggested that the past is unlikely to be addressed through a uniform process and that the industry would do better to be more attentive to the remedial theories, limitations and opportunities inherent in multiple forms of engagement, as these manifest in flashpoints of conflict that invoke legacy issues. Szabó (2013) suggested that the economic crisis has affected collective bargaining through two channels: direct economic challenges and political change. SA's economic challenges have led to the polarisation of the labour force in the private sector and further sternness in the public sector.

A study conducted by Price, Bailey and Pyman in 2014 concluded that an environment in which unions are not forced to fight to represent members can be conducive to collaborative employment relations, particularly in industries where the parties do not adopt an adversarial stance (Price et al., 2014). Bluestone and Kochan (2014) agreed that the continuing fiscal crisis facing the commonwealth countries and its municipalities can provide the motivation for forging a fundamental change in public sector labour relations. This could not only lead to a more efficient and effective government service but could also play a critical role in improving public services and closing the achievement gap.

The dominance of competitiveness is a central frame reference in the wage policies of different trade unions (Cruces, Trillo \& Leonardi, 2015). This competitiveness has a negative impact on economic growth and social cohesion. Seldén (2014) concluded that competing discourses co-existed with regard to the measures to be taken, displaying important and historically rooted differences between trade unions regarding the context, scope and objectives of transnational collective action. A good stakeholder collective engagement strategy should, therefore, be able to fit within the environmental factors (past, present and future) that have an influence on the labour market and that have an impact on collective engagement processes.

\section{Global labour market influences}

Multinational firms pay above-industry average wages compared to local firms in the country in which they operate, thus impinging on competitors, and on employment policies of the labour market in general (Driffield, 2013). Multinational firms have bargaining power weakness when compared to local firms; first, because of their positions in global structures, and second, because of their desire to buy industrial peace which they can afford because of high volumes of productivity and profitability (Driffield, 2013). Most of the mining companies in SA are part of the global companies; hence, they pay higher averages in comparison with local companies in other sectors. The local mining companies are forced to compete with these global companies, putting strain on their financial outlook and causing them to fail in sustaining their businesses.

The labour market firms influence economic growth and impact the supply of key skilled workers to new and expanding firms, and the shedding of workers from declining and failing firms (Henrekson, 2014). Growth-favouring labour market institutions include the following as part of the payment package: portable pension plans and other job tenure rights, health insurance untied to the current employer, individualised wage-setting and public income insurance systems that encourage mobility and risk-taking. Blanton, Blanton and Peksen (2015) stated that organised labour has consistently been critical of International Financial Institutions (IFI) policy prescriptions attached to loans, as such policies harm workers' interests. On the contrary, these financial institutions refute the organised labour claims, arguing to the contrary that they work with relevant labour organisations and that many of their arrangements call for compliance with core labour standards (Blanton et al., 2015). It seems that very little research has been devoted to whether IFI programmes affect labour laws and the actual labour practices of recipient countries. It also seems that international financial institutes undermine collective labour rights and that policy reforms are necessary.

\section{Discussion}

In this article, the current literature has been reviewed according to the current collective engagement stakeholder strategies to establish their effectiveness and relevance. The conclusion is that most of the research conducted has been focused on collective engagement failures and that there is a need to pay more attention to future collective engagement strategies that will contribute positively to a harmonious labour relations environment. Figure 1 outlines the analysis of the current collective engagement stakeholder strategies and the gaps that need to be addressed. 


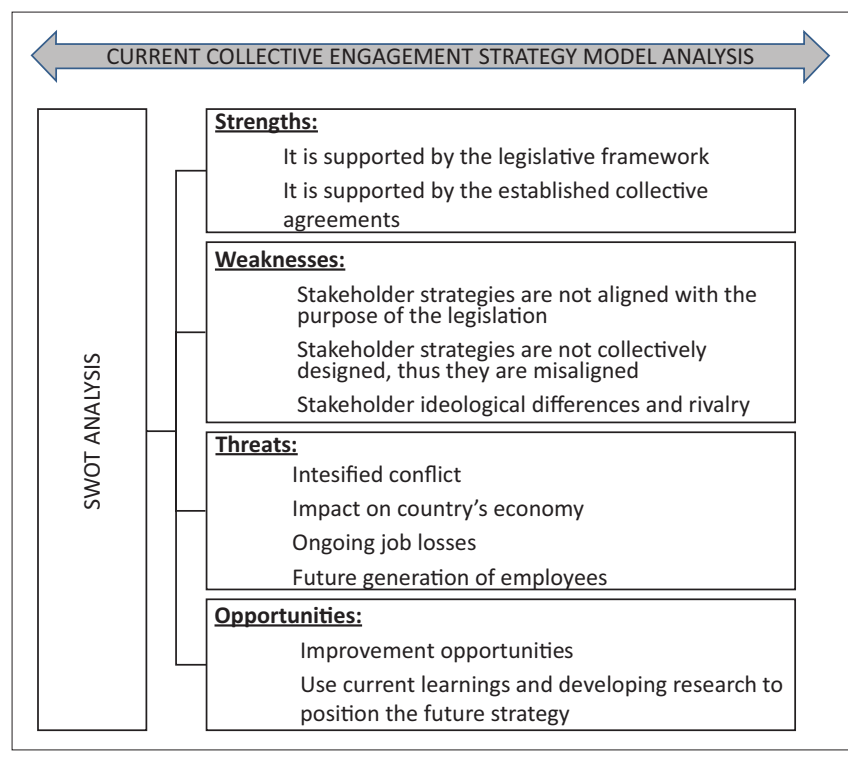

FIGURE 1: Current collective engagement strategy analysis.

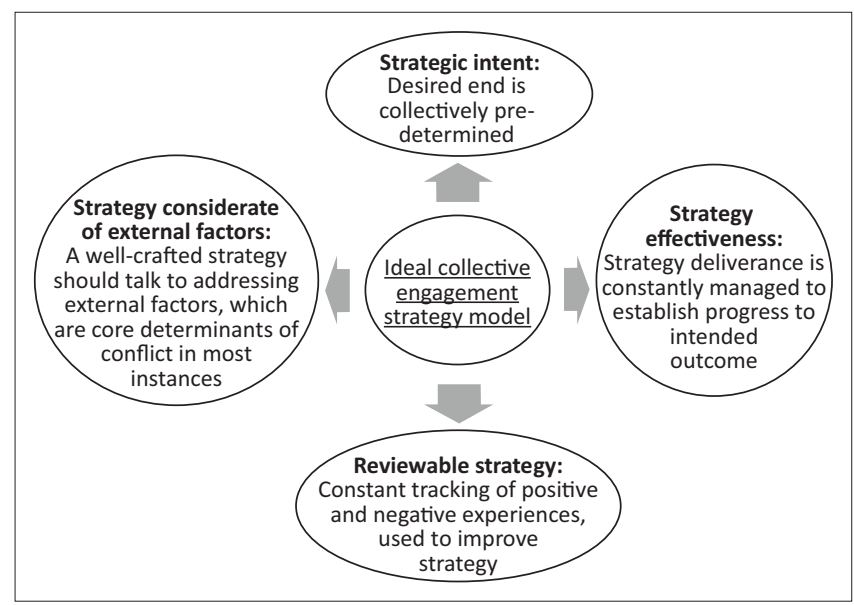

FIGURE 2: Proposed collective engagement strategic model.

Cognisance was taken of the evolving labour relations environment and the fact that there is a need for a constant review of labour strategies to sustain labour peace, meaning that empirical research in this area should be continuous. Based on the literature discussion, it is suggested that an effective stakeholder strategy should reflect the following: there should be strategic intent; there should be a clear analysis of past and current strategy impact to the labour relations environment to establish the future strategy; the strategy should be measurable; the strategy should be amenable to change where the new developments in the labour market dictate as much; the strategy should address not only wages and terms of employment but must also take cognisance of socio-economic and political factors that have a direct or indirect impact; and there should be a collective establishment of the strategy that is aligned with other similar business sectors.

The review of the current labour relations challenges and weaknesses, together with the analytical suggestions, resulted in a proposed strategic model for harmonious collective engagement in SA. Figure 2 proposes what a possible future labour relations strategic model should consider with regard to strategic intent, strategy effectiveness, reviewable strategy and impact of external factors.

Figure 2 suggests a collaborative approach in the development of strategies, either at plant or central bargaining levels or at policy formulating levels. Collective engagement stakeholder representatives should be able to predetermine critical matters of interest for any intended collective engagement and jointly adopt appropriate collective engagement strategies that are relevant for the purpose. A clear engagement agenda should be jointly generated and agreed upon, and should be measured as to whether it is responding positively, efficiently and effectively to matters of importance, both internally and externally.

\section{Conclusion}

This theoretical article presented an overview of the current stakeholder strategies for collective engagement for harmonious labour relations in the SA mining sector. The introduction and background presented the unstable and violent collective engagement processes in the employment relations environment in SA. The existing collective engagement strategies were identified and presented. A discussion of the suggestions and recommendations for harmonious labour relations in the SA mining sector resulted in a strengths, weaknesses, opportunities and threats (SWOT) analysis and a proposed collective engagement strategic model.

Although the current collective engagement framework in SA is sound and stable, the stakeholder's ability to create harmonious strategies supporting the framework is found to be lacking. Ideally, the country, and specifically the mining sector, should have a set of standards prescribing best practices for peaceful negotiations and resolutions of employer-employee-union conflicts.

\section{Acknowledgements}

The University of Johannesburg has funded this study.

\section{Competing interests}

The authors declare that they have no financial or personal relationships that may have inappropriately influenced them in writing this article.

\section{Authors' contributions}

P.C.M. is a student who conducted the research study into the collective engagement and stakeholder strategy for harmonious labour relations in a mining organisation, submitted in fulfilment of the requirements for the Master of Philosophy in Employment Relations degree. C.M.G. is a senior lecturer who supervised the study conducted and co-authored the production of this article. 


\section{References}

Benjamin, P. (2005). A review of labour markets in South Africa: Labour marke regulation: International and South African perspectives. Human Science Research Council. Retrieved n.d., from http://www.repository.hsrc.ac.za

Blanton, R.G., Blanton, S.L., \& Peksen, D. (2015). The impact of IMF and World Bank programs on labor rights. Political Research Quarterly, 68(2), 324-336. https:// doi.org/10.1177/1065912915578462

Bluestone, B., \& Kochan, T.A. (2014). Toward a new grand bargain: Collaborative approaches to labor-management reform in Massachusetts. Report. Boston, MA: approaches to labor-man
The Boston Foundation.

Chinguno, C. (2013). Marikana and the post-apartheid workplace order. Society, Work and Development Institute (SWOP), Working Paper No. 1. Braamfontein: University of the Witwatersrand.

Chinguno, C. (2015). The unmaking and remaking of industrial relations: The case of Impala Platinum and the 2012-2013 platinum strike wave. Review of African Political Economy, 42(146), 577-590. https://doi.org/10.1080/03056244.2015.1087396

Coleman, N. (2013). Towards new collective bargaining, wage and social protection strategies in South Africa - Learning from the Brazilian experience. Global Labou University, Working Paper No. 17. Retrieved November 17, 2013, from http:// www.global-labour-university.org

COSATU. (2012). Concept paper: Towards new collective bargaining, wage and social protection strategies - Learning from the Brazilian experience. Input to COSATU CEC. Retrieved May 28, 2012, from http://www.cosatu.org.za/docs/discussion/ 2012/cec_conceptpaper.pdf

Cruces, J., Álvarez, I., Trillo, F., \& Leonardi, S. (2015). Impact of the euro crisis on wages and collective bargaining in southern Europe - a comparison of Italy, Portugal and Spain. In G. van Gyes \& T. Schulten (eds.), Wage bargaining under the new and Spain. In G. van Gyes \& T. Schulten (eds.), Wage bargaining under the new
European economic governance: Alternative strategies for inclusive growth (pp. 93-137). Brussels: European Trade Union Institute.
.

Dawkins, C.E. (2014). The principle of good faith: Toward substantive stakeholde engagement. Journal of Business Ethics, 121(2), 283-295. https://doi.org/10.1007/ s10551-013-1697-z

Di Paola, M., \& Pons-Vignon, N. (2013). Labour market restructuring in South Africa: Low wages, high insecurity. Review of African Political Economy, 40(138), 628-638. https://doi.org/10.1080/03056244.2013.858432

DoL. (2012). Annual industrial action report. Pretoria: Government Printers.

Driffield, N. (2013). Global competition and the labour market. Routledge. Retrieved May 13, 2013, from http://www.routledge.com

Elgoibar, P., Munduate, L., \& Euwema, M. (2016). Building Trust and Constructive Conflict Management in Organizations: Industrial Relations \& Conflict Management. Cham: Springer.

Farlam, I.G., Hemraj, P.D., \& Tokota, B.R. (2015). Marikana commission of inquiry: Report on matters of public, national and international concern arising out of the tragic incidents at the Lonmin mine in Marikana, in the North West Province. Retrieved March 13, 2015, from http://www.lonmin-farlam.com

Grimshaw, D., Bosch, G., \& Rubery, J. (2014). Minimum wages and collective bargaining: What types of pay bargaining can foster positive pay equity outcomes? Britis Journal of Industrial Relations, 52(3), 470-498. https://doi.org/10.1111/bjir.12021
Hartford, G. (2012). The mining industry strike wave: What are the causes and what are the solutions? GroundUp. Retrieved October 10, 2012, from http://groundup.
org.za/content/mining-industry-strike-wave-what-are-causes-and-what-areorg.za/content/mining-industry-s
solutions\#sthash.blKcK2zl.dpuf

Harvey, R. (2013). Releasing the prisoners from their dilemma: How to resolve labour tensions in South Africa's mining sector. Cape Town: SAllA. (n.d.). Retrieved from https://www.africaportal.org/documents/11211/saia_spb_81_harvey_2013 1231.pdf

Henrekson, M. (2014). How labor market institutions affect job creation and productivity growth. IZA World of Labor. https://doi.org/10.15185/izawol.38

Humby, T.L. (2016). Redressing mining legacies: The case of the South African mining industry. Journal of Business Ethics, 135(4), 653-664. https://doi.org/10.1007/ s10551-014-2380-8

Kruger, J., \& Tshoose, C.I. (2013). The impact of the Labour Relations Act on minority trade unions: A South African perspective. PER: Potchefstroomse Elektroniese Regsblad, 16(4), 1-45.

Lester, D.B. (2014). Employee participation in decision making in the mining sector Doctoral dissertation. Cape Town: University of the Western Cape.

Nwankwo, N.U. (2016). The role of collective bargaining on management and labour relations: A case study of First Aluminium Company Limited and West African Glass Industry Limited Port Harcourt. Doctoral dissertation. Enugu: University of Nigeria.

Organization for Economic Co-operation and Development (OECD). (2000). Tackling inequalities in Brazil, China, India and South Africa: The role of labour market and social policies. Paris: OECD.

Price, R., Bailey, J., \& Pyman, A. (2014). Varieties of collaboration: The case of an Australian retail union. The International Journal of Human Resource Management, 25(6), 748-761. https://doi.org/10.1080/09585192.2012. 743477

Roberts, K. (2015). Does collaborative bargaining make a difference in nursing agreements? East Lansing, MI: Michigan State University.

SABPP. (2015). Where did it all go wrong? Findings of the Farlam Commission Report How Lonmin Employment Relations Management practice compared to the SABPP HR Management Standard on ERM. Parktown: SABPP.

Sachs, B.I. (2013). The unbundled union: Politics without collective bargaining Yale Law Journal, 123(1), 148-207. Retrieved October 08, 2013, from https://ssrn. com/abstract $=2337561$

Seldén, K.L. (2014). Laval and trade union cooperation: Views on the mobilizing potential of the case. International Journal of Comparative Labour Law and Industrial Relations, 30(1), 87-104.

South African Government. (2015). Labour Relations Act, no. 66, of 1995, amended in 1996, 1998, 2002, 2015. Pretoria: Government Printers.

Szabó, I. (2013). Between polarization and statism - effects of the crisis on collective bargaining processes and outcomes in Hungary. Transfer: European Review of Labour and Research, 19(2), 205-215.

Webster, E. (2013). The promise and the possibility: South Africa's contested industrial relations path. Transformation: Critical Perspectives on Southern Africa, 81(1) 208-235. https://doi.org/10.1353/trn.2013.0000 